UDK: 331.5:159.9

POSLOVNA EKONOMIJA BUSINESS ECONOMICS

Godina XIV

Stručni rad

Broj 1

Str $52-65$

doi: 10.5937/poseko17-26807

PhD Zsolt Kőmüves, ${ }^{1}$ associate professor

Faculty of Economic Science of Kaposvár University

Institute of Marketing and Management

Viktória Petrás, ${ }^{2}$ PhD student

Faculty of Economic Science of Kaposvár University

Institute of Marketing and Management

MSc Stella Vig Salma, ${ }^{3}$ Teaching Associate

Educons Univerzitet, Sremska Kamenica

Fakultet poslovne ekonomije

\title{
ANALYSIS OF FACTORS THAT INFLUENCE THE EMPLOYMENT OF MOTHERS WITH SMALL CHILDREN IN HUNGARY
}

\begin{abstract}
For women with young children, work and parenting are not mutually exclusive, but both are key. Together, the two help them live a full life. At the same time, they can still face a lot of job disadvantages, and those who manage to reconcile the two may have a privileged background. Based on the literature and its further reflection, we list the factors hindering the employment chances of women with small children.
\end{abstract}

Key words: motivation, state aid, education, equal opportunities.

${ }^{1}$ Kömüves Zsolt, $\mathrm{PhD}$, associate professor

${ }^{2}$ Viktória Petrás, PhD student

${ }^{3}$ Vig Salma Stella, Msc, saradnik u nastavi 


\section{INTRODUCTION}

Increasing women's market participation and improving their employment rates are crucial for achieving $75 \%$ of the working population aged 20-64 by 2020, which is a key objective of the European 2020 strategic program. Achieving this can also have a significant impact on three important economic and social areas. The first is economic growth: if women's activity rates catch up with men, Europe's GDP would be 12 percent higher over the next 15 years (Engelhardt, Kögel, \& Prskawetz, 2004). The second area is low fertility (Brewster \& Rindfuss, 2000). We know that a woman who does not feel financially secure postpones having a child (Szalai, 2015). The third critical area is the issue of pension insurance arising from low fertility. As women are a potentially highly educated working-age population, increasing their labor market activity can also help in this area (Szabó, Woman in the market labour, 2018). In our study, we want to examine which factors directly or indirectly affect their employment, labor force market integration. To explore this, we review the available domestic and international literature, paying particular attention to employment, education, and equal opportunities. As a first step, let's review domestic employment data.

\section{EMPLOYEMENT}

The most important data on the participation of the two non-labor markets are presented in Table 1.

Table 1. Two genders' employment indicators

\begin{tabular}{|l|c|c|c|c|}
\hline \multicolumn{1}{|c|}{ Period } & $\begin{array}{c}\text { Unemployment } \\
\text { rate }\end{array}$ & Employment rate & $\begin{array}{c}\text { Unemployment } \\
\text { rate }\end{array}$ & Employment rate \\
\hline & Men & Men & Women & Women \\
\hline 1992.01. & 10,8 & 64,6 & 8,8 & 52,3 \\
\hline 1996.01 & 10,7 & 60,1 & 8,8 & 52,6 \\
\hline 2000.01 & 7,0 & 63,3 & 5,6 & 49,7 \\
\hline 2010. I-IV. & 11,7 & 59,9 & 10,7 & 50,2 \\
\hline 2012. I-IV. & 11,4 & 61,6 & 10,7 & 51,9 \\
\hline 2014. I-IV. & 7,6 & 67,8 & 8,0 & 55,9 \\
\hline 2016. I-IV. & 5,2 & 73,0 & 5,1 & 60,2 \\
\hline 2017. I-IV. & 3,8 & 75,2 & 4,6 & 61,3 \\
\hline 2018. I-IV. & 3,5 & 76,3 & 4,0 & 62,3 \\
\hline 2019. I-IV. & 3,4 & 77,3 & 3,5 & 63,0 \\
\hline
\end{tabular}

Source: (KSH, Two genders' employement indicators, 2019)

In the 1980s, full employment was achieved for both men and women. Then, as a result of the economic transformation following the change of 
regime, women were permanently excluded from the labor market at a higher rate than men. The economic transformation after the change of regime forced an increase in productivity and a drastic decrease in labor demand, which fundamentally affected the strategic processes of companies

(Szigeti, 2010). In six years, the employment rate of able-bodied women fell from 67.3 per cent to 45.5 per cent and that of men from 82.9 per cent to 60.1 per cent. At the 1996 low, just over half (52.6 per cent) of the working-age population worked, 42 per cent were inactive, more than half of the unemployed could not find a job for more than a year, and thus the proportion of the long-term unemployed exceeded that of the active age population 3 percent ( (Fazekas \& Scharle, 2012). In Hungary, employment stabilized in 1997 after the change of regime, then expanded by 1-3\% per year until 2003, the share of employees was around $57 \%$ until the global financial crisis that erupted in 2008, For the first time, the crisis pushed back men's employment, with a sharp rise in unemployment among them, due to the male dominance of the crisis sectors (car manufacturing, construction). As a result of the crisis, another age group of women - those aged 20-24 - has been disadvantaged in terms of the labor market (Vajda, 2015). Meanwhile, in 2013, the number of employees was at an all-time high. However, this record did not cover significant progress. The increase was partly due to the large number of people in public employment and partly due to the spread of part-time employment. Between 2011 and 2016, female activity increased the most among 15-19 year olds who did not complete primary school, mainly due to the lowering of the compulsory school age. The activity of the 60-64 age group has also increased due to the gradual extension of the retirement age. Among those of the best working age, those with lower education increased their labor market activity to a greater extent as a result of expanding public employment (Varga, 2018). 2019 I - IV. In the third quarter, employment of both sexes continued to grow. There was a significant improvement among men, as a result of which the differences between the two non-employment levels widened further. The lower employment rate of women is mainly explained by the fact that they are traditionally responsible for caring for family tasks related to childcare and family, which is why they are mainly temporarily excluded from employment. In addition, a large proportion of them took advantage of the retirement benefits available after 40 years of employment and quit their gainful activities. The culmination of the rate gap occurs among those aged 30-35 and around 60. The employment rate of $75.2 \%$ of the population aged $20-64$ has reached the $75 \%$ employment target set in the Europe 2020 strategy. The employment rate of $83.0 \%$ of men 
in this age group was significantly higher than that of women, of whom $67.5 \%$ were employed in I - III of 2019. quarter. (KSH, 2019) ${ }^{4}$ area".

In the next step, we will outline what steps have been taken in recent years to improve the labor market and social situation of women with small children. nearly 220,000 women have already lived. The Workplace Protection Action, introduced in 2013, helped mothers with small children by encouraging employers to expect mothers again after having children, even part-time. In 2018, more than 33,000 mothers took advantage of the benefits. In 2014, the government will introduce GYED Extra ${ }^{5}$, so families with small children do not have to choose between work and GYED, the parent will receive the full amount of benefits even if the parent goes back to work, even in full-time employment. Since 2016, the system has become even more flexible, as you do not have to wait for the child's one-year-old, the parent can work indefinitely with his or her six-month-old child by receiving the full amount of GYED in addition to his or her income. This measure also had an incentive effect on fathers, with Emmi's State Secretariat for Family and Youth saying that not only had the number of parents in GYED jumped, but there had also been a significant change in the gender distribution of claimants. While in December 2016 only 4.7 per cent $(4,371$ people) of the parents with 92,740 GYEDs were men, by 2018 there were already 8,057 fathers living with the benefits, this is 8 per cent of the 99,362 GYED parents. Family and work In order to support the balance of education and to train and keep mothers with small children up to date, 67 Family and Career Points will be established in the country in 2018. From 2018, the duration of the Student GYED was doubled. From 1 January 2018, mothers who have a Student Loan and are taking on a child may be partially or even fully exempted from repaying the Student Loan.

After reviewing the current labor market situation and government measures, let us move on to examine what is typical of the labor market situation of mothers with small children. Reconciliation of work and private life was in the first place, and general social inequality between men and women was in the second place (Szabó, Végvári, \& Gelencsér, Industry 4.0: economical and labour market impacts in Hungary, 2019).

However, the statements do not confirm this, as the employment rate of women raising children under the age of 6 is still significantly lower than that of those raising no or only school-age children. This shortfall is outstanding for those entitled to childcare. Although the presence of mothers between the ages of 25 and 49 raising children under the age of 3 increased significantly

\footnotetext{
${ }^{4}$ Hungarian Central Statistical Office

${ }^{5}$ Child care benefit
} 
Z. KÖMÜVES, V. PETRÁS, S. VIG SALMA, ANALYSIS OF $\ldots$ in the labor market compared to 2010 through government measures (Table 2), only $17.9 \%$ of them were still employed in 2019.

Table 2: Employment rate of women aged $25-49, \%$ by age of children

\begin{tabular}{|l|c|c|c|c|c|}
\hline $\begin{array}{l}\text { Age of child } \\
\text { / year }\end{array}$ & 2010 & 2016 & 2017 & 2018 & 2019 \\
\hline Under 3 & 12,4 & 14,2 & 15,2 & 15,4 & 17,9 \\
\hline $3-5$ year old & 58,5 & 71,9 & 73,7 & 75,3 & 75,1 \\
\hline $\begin{array}{l}6-16 \text { year } \\
\text { old }\end{array}$ & 74,5 & 83,5 & 85,1 & 84,9 & 86,8 \\
\hline $17-24$ & 80,4 & 88,3 & 88,6 & 89,3 & 90,0 \\
\hline $\begin{array}{l}\text { No child in } \\
\text { the } \\
\text { household }\end{array}$ & 77,4 & 86,3 & 87,3 & 87,7 & 87,8 \\
\hline
\end{tabular}

Source: (KSH, 2019)

However, we must also note that the employment rate for women is declining with the increasing number of children (Table 3 ). The employment rate of those raising 3 or more children was still more than 20 percentage points lower in 2019 than that of two children, but compared to 2010, their employment rate increased the most. It is believed that the special tax benefit for large families can often only be fully utilized by two parents together.

Table 3: Employment rate of women aged $25-49, \%$ as a function of number of children

\begin{tabular}{|l|c|c|c|c|c|}
\hline $\begin{array}{l}\text { Number of } \\
\text { children in the } \\
\text { household/year }\end{array}$ & 2010 & 2016 & 2017 & 2018 & 2019 \\
\hline 1 & 65,4 & 73,6 & 73,3 & 72,3 & 73,4 \\
\hline 2 & 64,8 & 69,6 & 73 & 72,6 & 73 \\
\hline 3 or more & 37,1 & 48,8 & 48,9 & 52,4 & 51,7 \\
\hline $\begin{array}{l}\text { No child in the } \\
\text { household }\end{array}$ & 77,4 & 86,3 & 87,3 & 87,8 & 87,8 \\
\hline
\end{tabular}

Source: (KSH, 2019)

On the part of workers, the most deterrent to return stems from the placement of their children. Due to the extension of the childbearing age and the increase in the retirement age, grandparents can no longer help care for their children as they did a few decades ago when several generations lived together. For financial reasons, few can afford to have a babysitter or go to a private institution. Those who want to work full-time again in a nursery want to place their children. Thus, the labor supply of mothers with small children 
is significantly influenced by the number of crèche places (Figure 1). Let's see how this number has developed in recent years?

Figure 1: Changes in the number of crèche places and the number of children enrolled between 2010 and 2019.

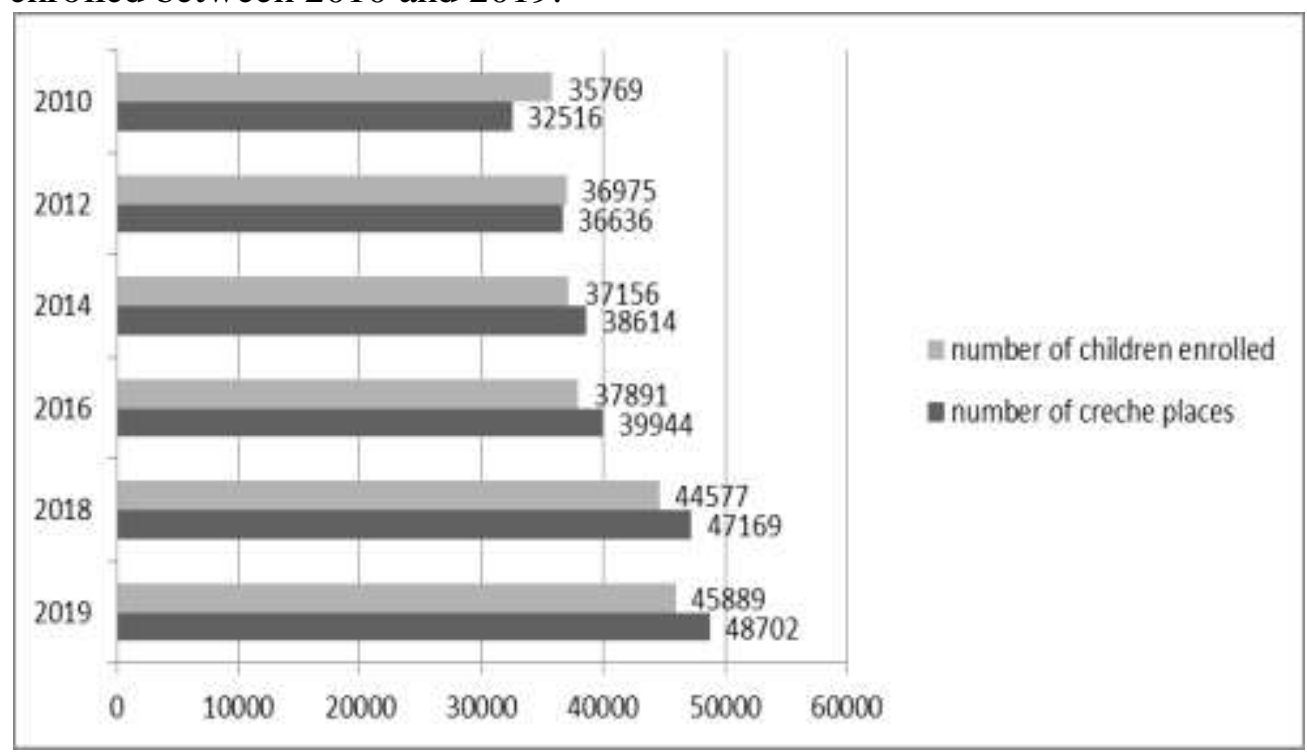

Source: (KSH, 2019)

In 2018, a total of 47,169 places were available to accommodate children in various forms of nursery care, while as of 14 November 2019, there were 50,920 places, occurred in the number of seats in the so-called mini nurseries. However, these favorable data are overshadowed by the fact that there were far more places than the number of children enrolled, ie the available approx. 50,000 seats, which can be explained by the fact that there were no vacancies where they would have been needed. Out of 3,200 settlements in Hungary, there are crèches in only 600 places, which means that 25,000 families do not have the opportunity to go to their crèches in the village or small town where they live. This is also supported by the fact that last year more than 33,000 young children were admitted to nursery institutions nationwide, but more than 3,800 were rejected due to lack of accommodation. In order to remedy this problem, it was announced at the beginning of August that parents returning to work who place their children over the age of 20 in a family or work crèche during the day can receive a subsidy of up to HUF 40,000 per month. The benefit is available to those who do not have nursery care or do not have enough space in their place of residence. According to a Eurostat survey, last year there were 88,000 Hungarians who did not work due to the lack of nursery care, or because of that they knew only less, even though they would have liked to have worked 
more. An important future task will therefore be to eliminate territorial inequalities. Opening up to flexible forms of employment.

It is common for a worker with a small child not to be able to return to the same position after maternity leave and employers in today's fastchanging world know nothing to do with a 3-year 'break' colleague whose knowledge is outdated or at least needs to be updated. Unfortunately, society and the labor market are not flexible enough, not to mention the employment situation. Few work telecommuting or part-time. In Hungary, the labor law regulatory environment creates an opportunity for companies to use various forms of flexible employment, but at the same time this alone is often not enough to actually make working conditions more flexible. Implementing such a change also requires a high degree of trust, an open leadership attitude, and proper documentation (Gergely \& Kocsis, 2018). The application of flexible forms of employment in Hungary lags behind other EU, mainly northern and western member states. Part-time employment can be an important aspect of reconciling work and family life (Figure 2). However, this has not spread equally between women and men: in 2018, 30.8\% of women aged 20-64 in the EU and 8\% of men worked part-time (ec.europa.eu, 2019). According to the Central Statistical Office, the number of part-time employees was only $9.3 \%$ of the total number of employees (of which women accounted for $6.8 \%$ and men for $2.5 \%$ ) and only a minimal increase was seen in the previous year. compared to years.

Figure 2: Part-time employment in Hungary 2004-2019

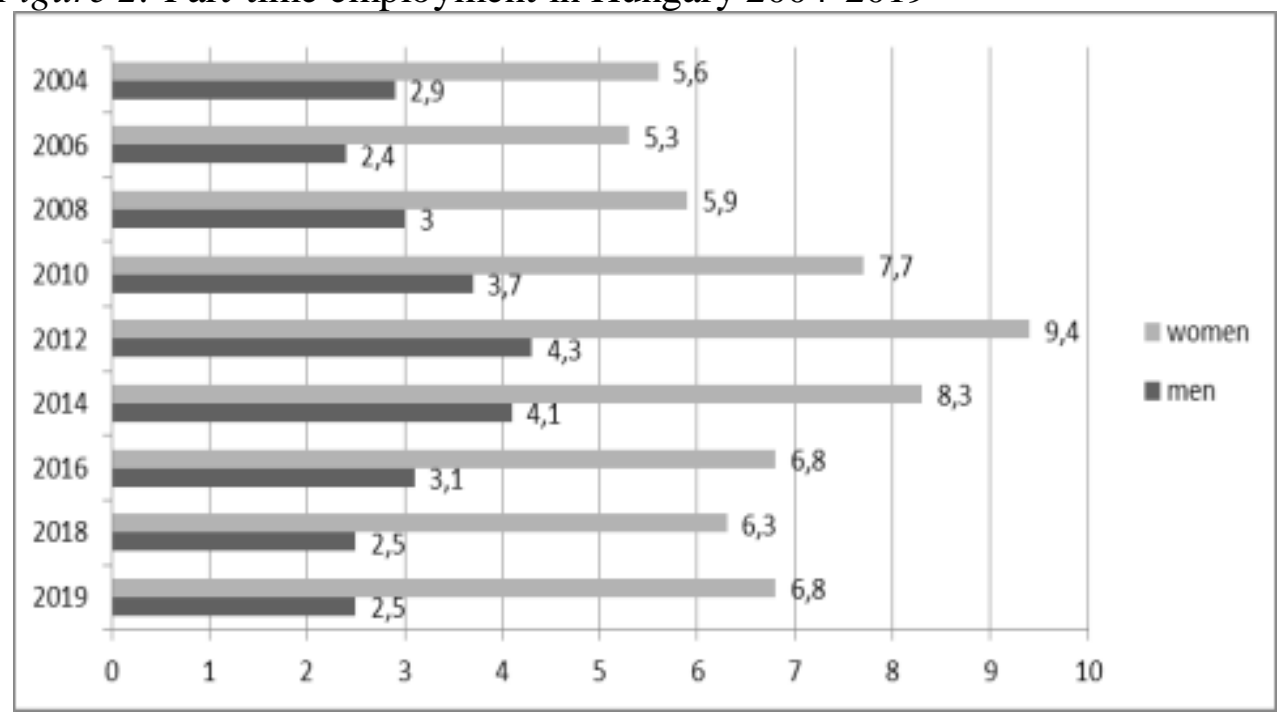

Source: (KSH, 2019. I-III. negyedév, 2019) 
Although some multinational employers have already recognized the potential of expectant mothers and have developed a program to support returning women, even ensuring that they return to the same leadership position as before childbirth, these are still very rare. There are many stereotypes about mothers with young children, who are a strong deterrent to employers, who, however, are losing a truly valuable workforce in the midst of growing labor shortages. Part-time jobs can be found almost exclusively in administration or assistants, although an eight-hour job requiring more serious expertise could be filled with two moms working four hours. It is also worth mentioning the importance of telework, whose role has increased, especially now during the coronavirus epidemic. According to a Eurostat survey, $2.5 \%$ of Hungarian workers worked teleworking in 2019 (1\% for women), and the importance of this form of employment is expected to increase rapidly with the spread of digitalisation. It can reduce per capita employment costs in the long run, recruit workers from a larger geographical area, and increase the company's attractiveness as an employer among jobseekers. regarding the use of forms.

Among the factors influencing employment, the issue of education is definitely worth mentioning. The increased employment of women has led to an increase in their level of education, thus their level of education compared to men, especially those of active earners, has largely leveled off. men. Among workers, the proportion of women with a low level of education (lower than primary school and primary school) was higher, the proportion of those with a secondary vocational education without a high school diploma was much lower, and the proportion of those with a tertiary education was slightly lower. However, a higher proportion of them had the highest level of education. In the younger age groups, however, as early as 1990, women were more educated than men. There was no difference between the sexes in the proportion of those with at least lower secondary education, ie primary education, but there was a higher proportion of women graduates than men, because in Hungary, similarly to several socialist and Scandinavian countries, the proportion of women in higher education was already 1981. reached and then exceeded 50 percent (Bavel, 2012). After the transformation, by 2011 women had already gained an advantage among the total population over 15 years of age in terms of the proportion of people with higher education, and then this advantage continued to increase until 2016 (Varga, 2018). Between 2011 and 2018, the number of low-educated people in the population aged 16-65 decreased among both men and women. Among women, the decline was very significant: from 800,000 in 2011 to 602,000 in 2018 . The number of women with tertiary education fell more sharply between 2017 and 2018 (by roughly 10,000 ) than the number of men with tertiary education, but still 
there remains a significant difference in the number of people with tertiary education between the two sexes in favor of women.

\section{WAGES}

UNICEF Hungary, with the support of the Indotek Group, conducted a comprehensive, representative survey of the labor market situation of mothers with small children (UNICEF, 2020). Research by the Publicus Institute, interviewing 1,002 people - 53 percent women and 47 percent men sought, among other things, how society relates to the reintegration of mothers with young children into the world of work. The resulting picture became very controversial. As it turned out, Hungarian society has a double expectation towards mothers with small children. While it is important for them to capitalize on their skills in the labor market as useful members of the community and contribute to the financial security of the family, they are not considered a full-fledged workforce. This is reflected in the definition of pay, leadership or employment criteria. The 1982 UN Convention on the Elimination of All Forms of Discrimination against Women11. Article 5 lists the equality rights to be guaranteed in the field of employment. These include the need to take into account the same selection criteria for individual candidates and the need to ensure the principle of equal pay for equal work. One of the most pressing labor market issues in all Member States of the European Union is to close the gender pay gap. There are several factors behind the pay gap: women are more likely to work part-time, find it more difficult to take up senior corporate positions, work in sectors with lower wages, and are often responsible for caring for family members and housework. The role of these factors could be reduced, for example, by improving work-life balance. The European Commission has also published the results of a Eurobarometer survey (ec.europa.eu, 2018) that looked at European citizens' perceptions of work-life balance. The results show, inter alia, that:

- Nearly a third (31\%) of Europeans under the age of 65 do not have access to flexible working conditions. In the case of Hungary, according to the respondents, this proportion is $10 \%$ higher (41\%).

- As far as paternity leave is concerned, on average in the EU, only $41 \%$ of men (under 65) have used or want to use this option. In Hungary, the same can be said for a third of the respondents.

- Both in the EU (52\%) and in Hungary (49\%), there is a high proportion of those who say that it is easier for women to go on family leave. Many are also convinced that taking time off has 
negative consequences for their careers: $39 \%$ of respondents at EU level and $30 \%$ of respondents in Hungary do so.

The European Parliament's resolution on the gender pay gap, adopted on 30 January 2020, highlights that the gender pay gap averages $16 \%$ within the Union. However, the elimination of wage discrimination is not only an ethical issue, but also economically and financially necessary for change. According to the resolution, the lower employment rate for women is about This would cost the European Union's economy EUR 370 billion, while increasing women's financial independence could have a very serious impact on reducing poverty (Transparency International 2020). According to a study by the Institute for Women's Policy Research, referred to in the European Parliament's resolution, the poverty rate would fall from $8.0 \%$ to $3.8 \%$ if women's wages were adjusted to those of men. In addition, the current number of 5.6 million deprived children would be reduced to 2.5 million. Equal pay is not only a matter of justice, but can also boost the economy through higher purchasing power. It is estimated that a $1 \%$ reduction in the gender pay gap would lead to a $0.1 \%$ increase in GDP (europarl.europa.eu).

Figure 3: Income differences between the two sexes in Hungary and the EU

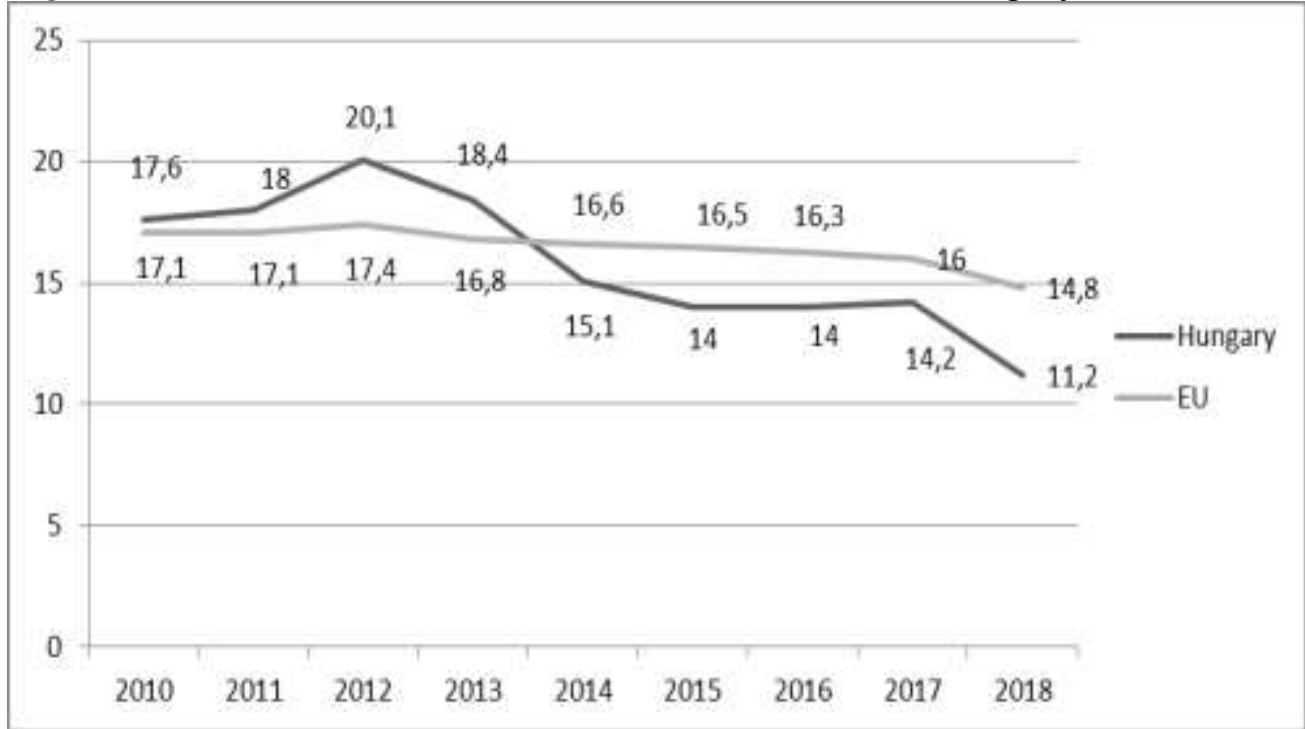

Source: (ec.europa.eu, Income differences two sexes in Hungary and the EU)

According to the data of the CSO's Labor Force Survey and the PES Wage Tariff Survey, the employment of women has increased significantly since the early 1990s, but the lag has remained almost the same compared to the employment of men. The inactivity rate of around 50 per cent in 1995 dropped below 40 per cent by 2017, but the lag compared to men is about the 
same - around 10 percentage points - as in the 1990s. Women's earnings dramatically approached those of men during the same period. In 1986, an average woman earned 75 percent of the salary of an average man. This ratio has improved to around 85-90 percent by 2016. The Equal Treatment Authority's research "Income inequality between men and women and gender segregation in today's Hungary" also reveals that the pay gap shows significant changes depending on age. . The research points out that there is no significant difference between the average income of women and men up to the age of 30 , and it does not change much after the age of 40 . So between the ages of 30 and 40, the pay gap develops quickly and significantly. It is important to point out that women's earnings typically increase in the early active years and then stop after a while - this is what the literature calls the glass ceiling phenomenon. This is why women's incomes in the top 20 percent are markedly lower than men's. "Women's income disadvantage of more than 10 percent is 'produced' by inequality among those with the highest incomes alone." - read in the study (Kozma, 2020).

\section{SOCIAL NORMS, ATTITUDES}

The return to work of mothers with young children can also be hampered by social norms and attitudes in public life. In Hungary, the social belief that it is good for a child if the mother stays at home until the age of three has been holding on for a long time. In both 2014 and 2016, the CSO conducted a survey on attitudes related to staying at home or returning a child before the age of three, and in both cases three-quarters of respondents preferred home childcare (Makay, 2018).

\section{FAMILY FRIENDLY WORKPLACES}

In countries where the employment of women with small children is high (eg Denmark, the Netherlands, Slovenia, the Scandinavian countries), a higher proportion of family-friendly workplaces that take into account the needs of young children (breastfeeding or changing rooms, childcare, crèche, flexible working hours), teleworking) There are many benefits to becoming a family - friendly workplace: it helps you choose the right workforce, increases employee loyalty, not to mention improves the company 's image to partners, customers and job hunters. However, surveys show that employers often do not think the same about family-friendly measures as employees (Hrportal, 2008). contact with your existing employee. According to a recent study, there is a contradiction between the attitudes of women with small 
children and society / employers towards employment. The two parties need to know each other's opportunities and needs in order to see women with small children not as a disadvantaged worker but as a potential source of labor, and so that women can return to work with confidence and selfadvocacy (Lipták \& Matiscsákné, 2018).

\section{CONCLUSION}

For women with young children, work and parenting are not mutually exclusive, but both are key. Together, the two help them live a full life. At the same time, they can still face a lot of job disadvantages, and those who manage to reconcile the two can be privileged. Based on the literature and its further reflection, we list the factors hindering the employment chances of women with small children.

These are the followings:

Perhaps one of the most burning issues is increasing the number of crèche places. There are currently about 50,000 places in the country, which have risen one and a half times, but their territorial distribution is unequal, with only 600 places in Hungary out of 3,200 settlements.

- Typical forms of employment that promote the maintenance of work-life balance, in general the higher employment of women, which are also made possible by the Labor Code, are not very widespread. Part-time employment, which is perhaps the most conducive to reconciling early childhood education and employment, is extremely low.

- One of the most effective ways to retain employees is to introduce a family-friendly workplace, where employees feel that not only do they go to work day in and day out, but the company can be, or at least support, one of the arenas of their family life. It also provides for the development of family life. However, this requires changes in the structure, rules and systems within the company with the help and support of management.

- It is important to change the traditional principles, stereotypes and attitudes that a woman's place is at home next to the child. It should be emphasized that the proportion of women raising their children alone or the number of women with a degree is significant, but the majority of those with lower education do not necessarily want to be bound to home, which also goes for Hungarian households.

- It is essential to formulate an equal opportunities strategy and action plan derived from the national strategy, to ensure and monitor the conditions for implementation. Equal pay and employment is also an 
interest in national strategy. Currently, the pay gap between men and women is over $14 \%$.

We emphasize the social dissemination of the equal opportunities approach and conclude that its inclusion in aid is not yet very common among the Member States.

\section{REZIME ANALIZA FAKTORA KOJI UTIČU NA ZAPOŠLJAVANJE MAJKI SA MALOM DECOM U MAĐARSKOJ}

Rad i roditeljstvo su za žene s malom decom od krucijalnog značaja i međusobno se ne isključuju. To ovim ženama pruža mogućnost da vode u potpunosti ispunjen život. Međutim, majke male dece se još uvek suočavaju sa mnogim preprekama i razlozima koji idu u prilog tome da ne bi trebalo da rade, a one žene koje uspevaju da pomire rad i roditeljstvo se smatraju privilegovanim.

U radu su prikazani faktori koji sprečavaju mogućnosti zapošljavanja žena sa malom decom na osnovu analize relevantne literature.

Ključne reči: motivacija, državna pomoć, obrazovanje, ravnopravnost

\section{REFERENCES}

1. Bavel (2012). The reversal of gender inequality in education, union formation and fertility in Europe. In Yearbook of Population Research, (old.: 127-154). Vienna.

2. Brewster , \& Rindfuss (2000). Fertility and Woman's. Annual Review of Sociology, 271-296.

3. ec.europa.eu (2018. 10 ec.europa.eu/hungary/news/20181026_equalpayday_hu

4. ec.europa.eu ec.europa.eu.

https://ec.europa.eu/eurostat/statisticsexplained/index.php/Employment_statistics

5. Engelhardt, Kögel, \& Prskawetz. (2004). Fertility and Woman's Employement Reconsidered. Population Studies, 9-20.

6. Fazekas, \& Scharle. (2012) Retirement, assistance, public works 19902010. Munkaerö-piaci látlelet, 2-7.

7. Gergely, \& Kocsis (2018). Megakom. Forrás: http://www.megakom.hu/?p=3482\&lang=hu 
8. Hrportal (2008. 8 15). Forrás: https://www.hrportal.hu/hr/milyen-isvalojaban-a-csaladbarat-munkahely-20080815.html

9. Kozma (2020. 2 26). A nemek közötti bérszakadék felszámolását sürgeti az EU. Letöltés dátuma: 2020, www. korrupcio.blog.hu: https://korrupcio.blog.hu/2020/02/26/a_nemek_kozti_berszakadek_fels zamolasat_surgeti_az_europai_parlament

10. KSH. (2019) Központi Statisztikai Hivatal. Forrás: Munkaerö-piaci esélyegyenlöség : //www.ksh.hu/thm/2/indi2 3 3.html

11. KSH. (2019) Munkaerőpiaci folyamatok, 2019. I-III. negyedév. Forrás: https://www.ksh.hu/docs/hun/xftp/idoszaki/mpf/mpf193/index.html

12. KSH. (2019) Two genders' employement indicators. KSH.

13. Lipták, \& Matiscsákné. (2018). Employment situation of women with small children. Vezetéstudomány, 41-51.

14. Makay (2018). Family support. In Monostori, Öri, \& Spéder, Demográfiai portré (pp.: 83-102). KSH.

15. Szabó. (2018). Woman in the market labour. In Munkaerö-piaci tükör (pp: 39-201). MTA Közgazdaság- és Regionális Tudományi Kutatóközpont Közgazdaság-tudományi Intézet.

16. Szabó, Végvári, \& Gelencsér. (2019) Industry 4.0: economical and labour market impacts in Hungary. Kaposvári Egyetem, (pp.: 93). Kaposvár.

17. Szalai. (2015. december) Family and Work: Comparative Analysis of the Employment of Women (D. L.n. Csaba, Szerk.) Polgári Szemle.

18. Szigeti (2010). Fundamentals of marketing strategy and marketing tools. In P. K. Szakály, Marketing a hagyományos és tájjellegü élelmiszerek piacán (old.: 98-100). Kaposvár: Kaposvári Egyetem.

19. Vajda (2015). Barriers for Woman in the Workplace. In M. N. Szövetség, A nőtlen évek ára (old.: 99-151). Budapest: Magyar Női Érdekérvényesítő Szövetség.

20. Varga (2018). Woman in the market labour. In Á. S. Morvai. Budapest: MTA Közgazdaság- és Regionális Tudományi Kutatóközpont Közgazdaság-tudományi Intézet.

Ovaj rad je primljen 05.05.2020., a na sastanku redakcije časopisa prihvaćen za štampu 10.09.2020. godine. 